\title{
SNAP, campus food insecurity, and the politics of deservingness
}

\author{
Maggie Dickinson $^{1}$ (1)
}

Accepted: 25 September 2021 / Published online: 14 October 2021

(c) The Author(s), under exclusive licence to Springer Nature B.V. 2021

\begin{abstract}
Many low-income college students are barred from food assistance for no reason other than the fact that they are pursuing a college education. Based on 22 interviews that capture the experiences of food insecure college students as they attempt to navigate SNAP, this study shows how low enrollment in the program and food insecurity are the predictable outcomes of policy decisions intended to restrict access to both free public higher education and public assistance in the 1980's and 1990's and were shaped by the racialized politics of deservingness. By documenting the barriers students encounter attempting to access food assistance, this study shows how these policies play out in the lives of students at the City University of New York (CUNY) today. Ultimately, the politics of deservingness create significant direct and indirect barriers to SNAP enrollment for students and limit policy makers' and advocates' attempts to expand SNAP and address food insecurity on college campuses.
\end{abstract}

Keywords SNAP · Food assistance $\cdot$ Higher education $\cdot$ Food insecurity $\cdot$ Racism

\section{Introduction}

Ideas about college students and SNAP (the Supplementary Nutrition Assistance Program formerly food stamps) have shifted dramatically over the past 40 years. SNAP is the largest, federally funded anti-hunger program in the United States. Once considered undeserving of food assistance, college students have become a prominent face of food insecurity and hunger in the U.S. today (Laterman 2019). As college students have emerged as a sympathetic group in need of assistance, advocates have pushed for solutions to address campus food insecurity, including increasing enrollment in SNAP. However, campus-based efforts to enroll students are limited by complex SNAP restrictions put in place in the early 1980's that render all full-time college students ineligible for the program unless they work $20 \mathrm{~h}$ a week or meet one of a number of other exemptions.

The result of this complicated policy configuration is that today many low-income college students are barred from food assistance for no reason other than the fact that they are pursuing a college education. While overall SNAP

Maggie Dickinson

Maggie.dickinson@guttman.cuny.edu

1 Department of Interdisciplinary Studies, Guttman

Community College, CUNY, New York, NY, USA enrollment has expanded in the 21st Century (Dickinson 2020), college students have been left behind due to policies that exclude them from food assistance. As with all public benefits, complicated eligibility rules and application processes dampen enrollment, even for people who are eligible for the program (Herd and Moynihan 2018). A Government Accountability Office (GAO) study estimates that only $43 \%$ of eligible college students - those who meet one of the student exemptions - are actually enrolled in the program-far lower than the $84 \%$ of all SNAP eligible U.S. residents who were enrolled in 2018 (Cunnyngham 2018; GAO 2019).

Looking to the experiences of college students at risk of food insecurity as they attempt to navigate SNAP, this study shows how low enrollment in the program and food insecurity among college students are the predictable outcomes of policy decisions intended to restrict access to both free public higher education and public assistance. After a review of the literature on campus food insecurity and SNAP, I situate SNAP student restrictions in their historical context, paying close attention to the racialized politics of deservingness. Next, I look at how these policies play out in the lives of students at the City University of New York (CUNY) today and how ideas of deservingness continue to limit policy makers' and advocates' attempts to expand SNAP for college students. 


\section{Background}

\section{Literature review}

Debates over college food insecurity have largely centered around the extent to which food insecurity among students is actually a problem (Nikolaus et al. 2019). For the purposes of this paper, food insecurity is defined as a condition of limited or uncertain access to adequate food (USDA 2020). Studies vary in the survey instruments used to measure food insecurity. Most use some version of the U.S. Department of Agriculture (USDA) food security survey module. Large scale, multi-campus studies and literature reviews have found high rates of college students experience food insecurity, ranging from 36 to $56 \%$. However, large scale studies are limited by their low response rates and lack of representative samples (Bruening et al. 2017; Goldrick-Rab 2016; Goldrick-Rab et al. 2017; Payne-Sturges et al. 2018). Many single campus and university-wide studies also find elevated rates of food insecurity, but they vary in their findings by type of institution and are not generalizable (Goldrick-Rab et al. 2019; Patton-Lopez et al. 2014 eg.). Studies drawing on national data on households with college students paint a different picture of college food insecurity. They find only slightly higher levels of food insecurity among households with a student attending community college, and rates of food insecurity close to the national average for households with students attending a four-year institution (Blagg et al. 2017). However, quantitative studies based on national data do not disaggregate students from their larger households, with whom they may or may not reside year-round. This data misses the lived reality of college students, including their varying levels of personal and financial independence, which is key to understanding their particular vulnerability to food insecurity. Qualitative studies find that food insecurity is caused by more than money - but also the time and transportation costs associated with college attendance (Peterson \& Freidus 2020). Researchers have called for national level data to be collected on food insecurity among college students to guide policy recommendations (Goldrick-Rab et al. 2017).

The data on low enrollment in SNAP among college students is limited, but less controversial. A GAO study found that only $43 \%$ of college students who are eligible for SNAP have enrolled in the program.(GAO 2019) While we know that many eligible college students do not enroll in SNAP, researchers are split on both the causes of low enrollment and the appropriate response-from removing SNAP student restrictions entirely to modifying them to allow a bit more flexibility to simply clarifying the language communicating eligibility rules to students.(Blagg et al. 2017; DukeBenfield \& Chu, 2020; Freudenberg et al. 2019; GAO, 2019)
Unexplored in this literature is the seeming paradox between high rates of food insecurity among college students alongside low rates of enrollment in SNAP, the nation's largest and most effective food assistance program.

No studies have elucidated the relationship between SNAP restrictions and overall low enrollment for college students, even among students who are eligible for the program. Further, none of this research has asked where SNAP restrictions for college students came from in the first place by situating them in historical context. In the absence of a historical accounting of SNAP college student restrictions and their on-going implications for today's college students, these debates overlook the ways that racism and the broader politics of deservingness in the post-Civil Rights era fundamentally shape college students' experience of food insecurity and SNAP today.

\section{Political context}

As welfare state scholars have long demonstrated, public benefits in the US are always shaped by raced, classed and gendered ideas of deservingness.(Hancock 2004; Quadagno 1996) Race and class played an important role in the implementation of college student SNAP restrictions in the late 1970 's and early 1980's. Food stamp restrictions for college students rose in tandem with attacks on free, public higher education in the U.S. Federal funding for free public higher education expanded dramatically in the 1960's, enabling low income people and students of color to enter higher education in unprecedented numbers (Taylor 2020). At the same time, organizations like the National Welfare Rights Organization, which grew out of the Civil Rights movement, successfully challenged many of the barriers to public assistance for Black families, expanding access to economic rights for Black people living in the U.S. (Nadasen 2004; Piven \& Cloward 1979).

Federal social safety net programs benefitting low-income people in the U.S. were established as part of the New Deal in the 1930's. But these benefits, like the Aid to Families with Dependent Children (AFDC) program that provided cash assistance for low-income families, were designed in ways that limited access to benefits for Black residents (Katznelson, 2005). The expansion of public benefits during the War on Poverty era in the 1960's was, in many ways, a response to the racism embedded in the New Deal welfare state programs (Quadagno 1996). Two of the most significant changes to the U.S. welfare state in this period were the establishment and growth of the modern food stamp program (Dickinson 2020) and an increase in AFDC rolls (Piven \& Cloward 1979).

In response to the gains of the Civil Rights movements, politicians and policy makers in the late 1960's began to 
deploy colorblind rhetoric around taxes and personal responsibility to undercut support for spending on social programs (Cooper 2017; Gilmore 2007; Hinton 2016). Restricting access to both higher education and the social safety net were intertwined priorities for conservatives intent on rolling back Civil Rights era gains. Ronald Reagan pioneered the kind of racist dog-whistle politics that were central to these political efforts (Haney-Lopez 2014). He used food stamps to explicitly link the expansion of both free college and what he saw as overly generous welfare support by pushing to cut food stamps for college students. He told a story about the need to cut benefits premised on a "young lady... who on the basis of being a student is getting food stamps, and she's studying to be a witch" (Jaffe 2021, p. 40). Much like the notorious welfare queen, Reagan presented a caricature of an undeserving, affluent college student living off the public's dime to justify changes in food stamp policy that harmed (and continues to harm) many students with real needs. Reagan's efforts to cut welfare programs, including food stamps and AFDC, were limited to small policy changes in the 1980's. However, cutting welfare programs became a bi-partisan political commitment with the election of Bill Clinton, whose 1996 welfare reforms fundamentally transformed the AFDC (renamed Temporary Assistance for Needy Families or TANF) program by instituting strict work requirements and time limits.

Food stamp restrictions for college students were instituted in tandem with the restructuring of higher education as a whole to shift the cost of college from the federal government to the private family and individual student. As Melinda Cooper notes, "the aim was both to cut budget deficits and to revive respect for authority by restoring the traditional role of parents and students in financing college costs" (Cooper 2017, p. 238). Federal legislators added restrictions to food stamps for full time college students in the early 1980 's to prevent presumably affluent young adults from receiving food assistance. Echoing Reagan, they justified these restrictions on the belief that full time college students, who may have qualified for food stamps because they had low incomes, were largely young, middle class and should be receiving financial assistance from their families rather than food assistance from the state.

Food stamp restrictions for college students were part of this broader effort to privatize the cost of college. A 1981 New York Times article urged Congress to 'tighten food stamps, but don't deprive the needy'. College students were foremost among the groups whose access to the program should be limited. But the evidence presented for these changes was largely anecdotal. Throughout the 1970's, news reports focused on college students' use of food stamps as opponents to the program "hammered home charges that the program subsidizes striking workers, affluent college students and hippie communes" (Charlton 1971; King 1975).
The narrative of undeserving college students living off of food stamps proved persuasive, resulting in major changes in the law in 1977 and 1980, which pushed $75 \%$ of enrolled college students out of the program (Roberts 1981).

The myth of the undeserving, affluent college student was effectively deployed to cut food stamps for college students across the economic spectrum. Though barring affluent, undeserving students from SNAP was the justification for adding numerous restrictions to the program, adding increased restrictions and complications to the program had the predictable effect of pushing people off of the food stamp rolls indiscriminately and making young people more reliant on their families to support them while they are in school. Given the racial dynamics of family wealth and income in the U.S., the push to increase dependence on family support for college disproportionately hurt Black and brown students (Hamilton et al. 2015).

To be fair, at the time SNAP restrictions were instituted, policy makers assumed that if a student did not have familial support, they would either be working or they would apply for public assistance. They included several exemptions; low-income students could still qualify for food stamps if they worked $20 \mathrm{~h}$ a week, were on public assistance, had a child under the age of 6 or a child between 6 and 12 and did not have access to childcare, were disabled, were enrolled in a federal work study program, or were enrolled in an employment training program. However, the restructuring of public assistance throughout the 1980's and 1990's undercut the public assistance exemption for students. The passage of welfare reforms in the 1990's pushed many lowincome college students off the public assistance rolls and out of college (Pearson 2007). The kinds of public benefits low-income students had access to in the early 1980's were far more robust than what students have access to today. The policy landscape has shifted since the early 1980's in ways that further disadvantage low-income college students beyond access to SNAP.

Enrollment Patterns at CUNY.

In 1993, 27,000 CUNY students were enrolled in cash assistance programs (Gittell 1996). At the time, this represented $13 \%$ of the entire student population. According to Hunter College's Welfare Rights Initiative, in 2019 only 2,000 CUNY students were enrolled in a cash assistance program-less than $1 \%$ of the total CUNY student population. This dramatic drop in access to cash assistance for low-income students was caused by changes to both federal and state policies. Federal welfare reforms passed in 1996 imposed time limits and strict work requirements on TANF (formerly AFDC) and led to a sharp drop in the rolls. In 1996 , TANF reached $68 \%$ of families below the poverty line with children nationally. In 2018, that figure had dropped to $22 \%$ and in some states like Texas and Louisiana TANF only reaches $4 \%$ of families below the poverty line today (Shaefer 
\& Edin 2012). Similarly, 13 states have eliminated their general assistance programs since 1989, which are programs that provide cash assistance for childless individuals. In each of the past three decades, some states have eliminated their General Assistance programs and others have cut funding, restricted eligibility, imposed time limits, and/or cut benefits (Schott 2020). Cuts to cash assistance programs have been motivated by anti-Black racism and have been most severe in states and municipalities with larger African American populations (Safawi \& Floyd 2020; Soss et al. 2011).

New York was no exception to this pattern. A 1996 CUNY Newsletter reported that new Human Resources Administration (HRA) requirements for New York's general assistance program, Home Relief, made it harder for recipients "to stay in school by removing the exemption for college attendance. It appears that thousands of students on Home Relief who wished to enter CUNY may have been deterred in the 1995-96 academic year, and many more who were previously enrolled may not have been able to continue" (Gittell 1996, p. 1). As researchers have noted, "the massive drop in caseload must be seen as an important mechanism in eliminating welfare as a pathway to postsecondary education" (Shaw et al. 2006, p. 7). The result is that many low income students who, in a previous era, would have qualified for food stamps because they were also enrolled in a public assistance program are now required to work at least $20 \mathrm{~h}$ a week or lose access to SNAP.

Just as more low income, first generation college students are pursuing a college degree (Taylor 2020), the safety net has been cut out from underneath them. Taken together, SNAP restrictions passed in the early 1980's and welfare reforms in the 1990's have increased the pressure on low-income students to work while they pursue a degree. Receiving even modest supports like SNAP are increasingly dependent on a student's ability to maintain employment. (Dickinson 2020). The weight of this policy history is borne by students who are turned down when they apply for SNAP because they do not meet any of the student exemptions and those who never bother to apply because they do not believe they are eligible.

The vast majority of college students today do not fit the ideal of the traditional college student attending college directly out of high school while being financially supported by their families. $71 \%$ of students nationally have at least one characteristic of non-traditional students (financially independent; one or more dependents; single caregiver, no traditional high school diploma; delayed college enrollment; enrolled part time; or employed full time during the school year) (GAO 2019). CUNY students are particularly vulnerable to these policies as they are balancing family commitments with work and school as they strive to get ahead (Freudenberg et al. 2019). At CUNY, 80\% of undergraduates are students of color, $61 \%$ are first generation college students, $53 \%$ work more than $20 \mathrm{~h}$ a week and $42 \%$ come from households with incomes under $\$ 20,000$ (CUNY 2018). CUNY students are living with the aftereffects of this policy history as they struggle to make ends meet while they are in school.

\section{Methods}

This research was part of a larger, IRB approved, mixed methods study conducted at the City University of New York in collaboration with Healthy CUNY and the CUNY Food Policy Institute. The study grew out of on-going efforts to end food insecurity at the university (Clarke et al. 2018). In order to understand the barriers to SNAP enrollment among college students, we partnered with CUNY's office of institutional research to administer a survey to a representative sample of students from three of CUNY's community colleges and two four- year colleges that matched all CUNY undergraduates by gender, age, race/ethnicity, cumulative grade point average, and class standing. Students who completed the survey were asked if they would be willing to participate in a follow up focus group. However, the survey coincided with the onset of the COVID- 19 pandemic and campus closures at all CUNY campuses. Instead of focus groups, we conducted, recorded, and transcribed telephone interviews with 22 individual students who had taken part in the initial survey. Students who agreed to participate in the focus groups were emailed an invitation to participate in a 30-45-min interview and asked to complete the 2-item food insecurity screen as a rough indicator of food security status (Hagar et al. 2010). Our interview sample reflected our interest in primarily capturing the experiences of students at risk of food insecurity. Of the 22 students who completed interviews, 20 answered yes to one or both of the food insecurity screening questions (13 answered yes to both and 7 answered yes to one) and were categorized as at risk for food insecurity. 2 answered no to both questions and were categorized as food secure. We also conducted informal interviews with staff on CUNY campuses engaged in SNAP benefits enrollment and attended several meetings with food pantry and benefits enrollment staff hosted by Healthy CUNY where staff discussed the challenges they encountered assisting students in applying for benefits. Both informal interviews and meetings were documented through fieldnotes. This study primarily presents qualitative data from student interviews that document the barriers they encounter attempting to access food assistance.

Using a grounded theory approach (Glaser \& Strauss 1967), questions for the interviews were developed based on emergent themes from the larger survey, which assessed student eligibility for SNAP, enrollment in the program, food insecurity, eating habits, and the self-reported impact 
of SNAP on academic performance. Interview protocols also drew from the long-standing work Healthy CUNY has done to assess and address food insecurity at the university (Clarke et al. 2018). Interviews focused on two dimensions: student eating habits during a typical week of classes and their experiences with public benefits and benefits enrollment. Our approach in the interviews was to draw out student experiences navigating the power structures that govern access to food and food assistance in order to "link complex macrostructural forces to the intricate micropolitics of everyday lived experience" (Harrison 2007, p. 27). As feminist ethnographers remind us, "it is the feminist practice of paying attention to power differentials that should guide methodological choice"(Davis \& Craven 2016, p. 84). Though power differentials between interviewers and research participants are inevitable, we drew on Dana Ain Davis's insight that people directly effected by welfare policy should be "valued as knowledge producers regarding the consequences of that policy" (Davis 2013, p. 33). As such, interviews paid close attention to the ways that students encounter, navigate, and understand the institutions that impact their ability to eat well, or at all, as they pursue a degree.

Two researchers read through each interview transcript to identify additional themes that emerged from the interviews and developed a set of descriptive codes that were used to analyze the transcript data (Saldaña 2014). A second round of analysis identified an additional set of codes related to power dynamics and administrative barriers to SNAP enrollment among students. All interviews were coded independently by two researchers and then compared for consistency around the themes (see appendix). All student names were changed to protect their anonymity. What emerged was a picture of the challenges students face in applying for SNAP as well as their beliefs and attitudes towards enrollment in the program.

In addition to interview data, I draw on secondary sources, archival newspaper accounts, and data from New York City's Human Resources Administration and CUNY to provide the historical context for the SNAP policies that create significant barriers for students. This context is important for understanding deservingness as a political project with real world effects - a project of organized abandonment in the face of expanded access to higher education and welfare benefits like food assistance in the Civil Rights era (Gilmore 2007). The historical genealogy of these sticking points - the places where students came up against barriers to food assistance - informs our discussion at the end of the paper of where to go from here.

\section{Findings}

\section{Direct exclusion from SNAP}

Student restrictions are a significant barrier to SNAP enrollment for a number of reasons. The first, and most obvious, is that students who would qualify for assistance if they were not enrolled in college can be excluded from the program. A New York City Department of Social Services (DSS) analysis of SNAP data from 2018 to 2019 shows that thousands of students are barred from the SNAP program each year for failure to meet the student eligibility criteria. The report found that in New York City, more than 2,000 students per year had their SNAP benefits terminated for this reason and more than 5,000 students per year had their SNAP application rejected for this reason (DSS 2020). At CUNY, our survey of $383^{1}$ CUNY students found that 191 were eligible for SNAP based on income and citizenship status. Of these 191 students, 32\% did not meet any of the student SNAP student exemptions. Though we do not know if these students actually applied for or received SNAP, we do know that approximately one third of students with incomes low enough to be eligible for SNAP would likely be denied benefits if they applied because they are pursuing a college degree.

Felicia, a student attending a four-year college and pursing a degree in biology described her experience applying for SNAP three years prior to our interview. "They denied me at that time because I didn't have a job. So, they said that one of the requirements if you're a food stamp student, you need to at least work $20 \mathrm{~h}$ a week. So, basically, you're telling me that I have to quit school so I'll be able to get a job. And when I get that job, I will need food stamps, but I'd be able to qualify. But I won't qualify because I need to be a full-time student. So, that doesn't make sense. And all she (the caseworker) says is, "I don't make the rules. You are not approved." Felicia was particularly concerned about the impact of working on her ability to keep up with her studies. "I don't think that food stamps is actually - SNAP is not really aware of that you work part-time, and then you go to school full-time. You're not gonna perform." Her experience demonstrates the ways that SNAP student restrictions play out in interactions with welfare office employees - creating confusion and frustration for students who are denied benefits because they are in school.

The complicated relationships between college student status, SNAP work requirements, and cash assistance programs creates considerable confusion for students in their

\footnotetext{
$\overline{1}$ The total $\mathrm{N}$ for survey responses was 504 , but due to missing data, we could only calculate SNAP eligibility for 383 survey responses. I use the $\mathrm{N}$ of 383 here to reflect that subsample for whom we could estimate SNAP eligibility.
} 
interactions with the welfare office. Diana, a student pursuing a two-year degree, described the administrative run around she experienced when she tried to apply for SNAP. Because she was not working, the welfare office tried to move her into a full cash assistance case when she tried to recertify her SNAP benefits. But cash assistance requires far more administrative oversight and reporting than SNAP and she most likely would have been assigned to a workfare position. "They told me that I had to quit school, so I would be able to just get on some type of program full-time. And I told them, no, I'm not doing that. I'm not quitting school, regardless of if you want to cut me off. Go right ahead, but I'm not doing that. They gave me the run around so many times to go get recertified, and - I've been to so many locations in the four boroughs. It's crazy. I've been a lot of places. I was like, no, I can't do this. They told me that, listen, you might have to drop out of school. And I'm like, I'm not doing that. Absolutely not. That's how he spoke with me, and I was like, this is crazy. It's like they wanted me to become a statistic, just to get - No. Absolutely not." Like Felicia, Diana felt pressured by case workers to drop out of school in order to receive SNAP, something she forcefully rejected.

Neither of these students were able to recertify their SNAP applications and they have never reapplied, despite significant food hardships. At the time of our interview, both students struggled with food insecurity and reported skipping meals. Even so, they did not have any interest in applying for SNAP again. As Diana put it, "I don't regret not going back on that. I can't. Personally, for me, I just don't want to go through that process again. If they improved, maybe? But I don't know if I want go back to that." The interactions that students like Diana and Felicia have with welfare office workers are not just isolated events. They deter students who feel mistreated from applying for SNAP in the future, despite on-going need.

\section{Indirect exclusion from SNAP}

SNAP restrictions for full time college students create a number of challenges beyond simply excluding low-income students who do not meet one of the exemptions. These include increased confusion about eligibility requirements, stigma, and challenges for college employees who are working to address food insecurity on campus.

Administrative burdens for public benefits deter people from applying and receiving benefits for which they qualify. The longer, more complex and more intrusive the application process is, the more likely it is that applicants will give up before they complete the process (Herd \& Moynihan 2018). Administrative burdens can take several forms. Herd and Moynihan define administrative burdens as the learning costs - or the time and effort it takes to learn about the program, whether or not you are eligible and how to apply; compliance costs including the time and effort required to comply with rules and requirements; and psychological costs including the stresses, loss of autonomy, and stigma associated with applying for a public benefit (Herd \& Moynihan 2018). Students experience different kinds of administrative burdens depending on their situation - from a lack of knowledge about how to apply, to confusion over eligibility rules, to the compliance costs of maintaining a job or a work study position to maintain eligibility.

High administrative burdens and confusion over SNAP eligibility deter students from applying if they have other economic options. Interview data sheds light on some of the dynamics at play in the economic calculus students make when thinking about food assistance. When asked why she had not applied for SNAP Cheyanne, a student at a 4-year college, said, "Okay, well I'm not in the absolutely desperate... I feel like I wasn't in a desperate enough position to warrant it. So, I never actually proactively got that for myself just because money was short for me, you know?" Though she reported skipping meals and eating less than she felt she should because of financial constraints, she was able to pursue more paid employment doing food delivery for Uber Eats and she took out a student loan to address the food shortages she experienced. She emphasized that she would have applied for SNAP if she had no other options. "Obviously if I' $m$ in the position where I can't eat period, then I really just don't have no choice (but to apply for SNAP)."

In Cheyanne's case, taking on more debt was preferable to applying for SNAP. She reported, "the first two months of the semester - I didn't have (money) to really feed myself ... It was just me kind of scraping by. I ended up also pulling a loan out too because of how hard the first three months were that I didn't want to spend the rest of the semester you know like scraping by with the work study budget and things like that. So, once I was able to get the loan, then I was in a more comfortable position where I didn't really have to worry as far as food and things like that." Increasing work hours and taking on student loans as strategies for dealing with food insecurity both come with costs. More work meant she had less time for studying. Taking on student loans that must be paid back can hurt a student's future financial stability. As other researchers have noted, rising costs of college are fueling heavy student debt loads and food insecurity among college students (Goldrick-Rab 2016). As a student with a work study position, Cheyanne would have met one of the exemptions for SNAP and qualified for the program if she had applied.

Why would she choose to pursue these sources of income, rather than apply for SNAP? For Cheyanne, stigma played a role in her decision. "I' $m$ sure there's still a stigma as far as being on public assistance like nobody ... especially when you're younger where you don't necessarily want to tell your friends that you're on SNAP or anything like that. You don't 
want to let people know as far as what your hardships actually are, and I think that the conversations opening up about hardships is still difficult in general and so to apply for a program is admitting that you have an issue." Researchers have often attributed low enrollment in SNAP among college students to stigma (Freudenberg et al. 2019), however stigma is produced in part by the kind of complex rules college students are subject to.

\section{Welfare stigma}

Cheyanne also expressed confusion over the eligibility requirements for SNAP as one of the reasons she chose not to apply. Student work requirements for SNAP caused her to conflate food assistance with the more restrictive and punitive cash assistance programs in New York City. She remarked, "I don't fully understand the requirements of it because like when I think of food stamps, I think of the welfare program as well where you know they don't allow you to have those provisions without committing yourself to a certain amount of work. So, I feel like they'll honor that if you're a part-time student, but if you're a fulltime student then it's okay but then if you're not working they're just like, "Well, you have to be working at the same time." For a lot of us, it's really not that easy to just be employed or not everybody wants to go to Job Corps and stuff like that." Cheyanne was aware of the SNAP work requirements for students, which she equated with the highly stigmatized workfare programs associated with cash assistance cases.

Cheyanne's concern about work requirements was not unfounded. Students who have cash assistance cases described the very real challenges cash assistance program requirements posed to their success as a college student. Devon was studying modern languages at a community college. He explained his complicated relationship with public benefits. He had enrolled in college directly out of high school but had to drop out because he was kicked out of his house shortly after he started college. He spent several years struggling with homelessness and insecure employment before re-enrolling in 2018. He got a job as a work study student in the tutoring center helping Spanish speakers with their English papers. "I was able to make enough money through work study that I really didn't have to worry about (food insecurity). At the time that I was tutoring, I was only getting the food stamps because I was making enough money in order that I didn't need additional assistance. So, all I needed was food assistance and medical insurance. But then there was a change in the fiscal budget for certain tutors in different tutoring programs and I was one of those student interns who got the snip. I was one of the casualties to something that was an executive decision."
Losing his work study job meant he had no income and had to figure something else out. He was also in danger of losing his SNAP benefits, since he no longer met one of the exemptions for full time college students. "I was trying to struggle just to make ends meet-not because I'm not willing to work, but because access to work is limited and then the jobs that are available would impact my ability to study because they require more time than I'm able to accommodate for. Because even if my class schedule is one thing, I still had to allocate time out of my personal schedule to study, which should equal the amount of time that I've been in a physical classroom. So, to add on a 40-h work schedule you know like yeah, I would do good because I'm making money. But then again, at the same time, the time management wouldn't be so great. I think I'll probably fail in class because I'm not dedicating myself to study as I ought to, you know?" Like many low-income students, Devon was engaged in a delicate balancing act between his need to survive and his desire to fully dedicate himself to his studies.

Concerned about the impact taking on a full-time job would have on his studies, he decided to turn to cash assistance as a means of income while he was finishing his degree. New York City still has a meager cash assistance program for single individuals with no children. His relatively smooth start to college, combining work in the tutoring center with SNAP to make ends meet, was completely derailed by the loss of this job. The requirements for a full public assistance case (cash assistance and SNAP) are far more challenging than for a SNAP only case (Dickinson 2016). As this student put it, "you have to comply with every single thing. It doesn't matter (if) you're going to die. If you have an appointment at 9am, you need to be at that appointment. The experiences that people have when interacting with Human Resources Administration employees- it can get really humiliating. To the point you just want to run away. You want to run away." Choosing to apply for public benefits in order to have the time to dedicate himself to his studies came with its own challenges, including poor treatment from welfare office workers.

He had to deal with multiple disruptions to his cash assistance case as a student, which often required him to miss classes to attend appointments with his caseworker. "I just hated the whole situation because it didn't really allow me to reflect who I am as a student because I was too busy dealing with problems. You know? I feel like I spend more time thinking about survival than I actually did about, "How else can I make this paper sound awesome?" The sense of stigma and disruption Devon experienced was echoed by Rozelynn, an older student finishing her B.A. who had a cash assistance case. As she put it, "the atmosphere is not welcoming. People that you interact with are not welcoming. They're condescending. It's just negative." Confusion about the SNAP student work requirements that cause students to 
conflate SNAP with cash assistance are a powerful deterrent to enrolling in the program.

\section{Administrative barriers to assisting students with SNAP applications}

Even CUNY staff members who assist students with benefits enrollment sometimes struggled to help them navigate the complex SNAP restrictions. All seven CUNY community college campuses have Single Stop offices that employ staff to assist with benefits enrollment and several four-year institutions offer benefits enrollment assistance to their students, often in connection with campus food pantries (Healthy CUNY 2020). Maria, a community college student whose SNAP application was denied because she was a student, described the ways the benefits enrollment office tried to assist her, to no avail. Employees in the office tried to connect her with a work study position in the campus food pantry so that she would be exempt from the work requirement. "For some reason, because I'm a full-time student, apparently it didn't work that time, so I'm not eligible for (SNAP). It was just weird I was trying to do work-study on campus, but obviously that didn't work out, So, it was like, well, I'm here (volunteering the pantry), so maybe that kind of compensates for me not working. And they didn't approve me. I mean, it was kind of stressful, Even the place I worked at, Single Stop, was like, I don't understand. You're a full-time student, paying bills, why aren't you - Why are you not somebody that be able to get the SNAP benefit?" The complexity of SNAP student restrictions makes assisting students with the application process far more difficult than for non-student applicants.

Maria struggled with serious food hardship, skipping meals, and seeking out informal networks of support. Like many students in this study, she felt that food insecurity interfered with her ability to succeed as a student. She found herself eating cheap snacks out of a vending machine because it was all she could afford or "a lot of just not eating" on the days she was on campus.

Employees who help students enroll in benefits on CUNY campuses confirmed that the SNAP work requirements for full time college students are one of the primary reasons students are denied much needed food assistance. They also felt that doing outreach to let students know about SNAP was complicated by the fact that many students would not qualify for benefits. In one campus Single Stop office, an employee expressed frustration because so few students could qualify for SNAP. She said, "we don't do much of that (SNAP enrollment) because (the students) don't work, so they can't get SNAP." Instead, most of her efforts went to running the campus food pantry. Though pantries are helpful in meeting immediate food needs, they are not able to offer the same level of assistance as SNAP (Poppendieck 1998) and they are less consistent in their ability to meet students' needs for food. The special SNAP restrictions that apply to college students make it difficult for on-campus employees to assist students and to do effective, broad-based SNAP outreach.

\section{Administrative burdens beyond student restrictions}

In interviews, students also reported administrative burdens that were not specific to their status as students, including long wait times at welfare offices, bureaucratic errors, and a belief that they would experience poor treatment that added to the sense of stigma often associated with applying for benefits like SNAP and public assistance. Jessica, a community college student, reported giving up after numerous attempts to follow up on an initial application. "No, I didn't try to apply again. Sometimes when I called the office, it would just be a really long wait time to actually speak to someone I think or you have these options, but it wasn't really - like you know you press a button for like if you need this or that, but there wasn't one where I could actually ask questions. So, I tried to speak to one and then I guess it just took too long and then I just I kind of gave up because it was kind of frustrating."

SNAP also requires many documents to certify enrollment, something some students found frustrating. Pratima, who was pursuing her B.A., explained, "it's one of the most annoying things in the world. You have to just like go and bring a whole bunch of documents. And then, you have to wait like three hours to be called. And then, you have to wait like another three hours the next day to be called, because it's not like a one-day thing. It's like, sometimes it takes a couple months, and you just have to keep going back. Sometimes, it interferes with your job. There were times where I had to call out, just because I had to go there with my parents."

CUNY campuses and New York City's Human Resources Administration have both made efforts to alleviate some of these administrative burdens. Since 2011, CUNY has hired staff to do outreach to inform students about public benefits and to assist with the enrollment process. HRA no longer requires people applying for SNAP to do an in-person interview and applicants can complete a SNAP application online and over the phone. Today the majority of SNAP applications in New York City are completed online, alleviating some of the administrative burdens noted by students we interviewed who recounted experiences applying for SNAP in person. Lowering administrative burdens, outreach, and enrollment assistance have been shown to increase enrollment rates in public benefits programs, including SNAP and have been effective for increasing enrollment in the general population in New York City (Finkelstein \& Notowidigdo 2019; Vigil 2019). But these changes may not be enough to 
counteract the extra administrative burdens college students face.

\section{Immigration status}

Indirect exclusion is particularly powerful among immigrant students. SNAP restrictions for immigrants added to the confusion and anxiety students from immigrant households experienced when they consider applying for SNAP. $35 \%$ of CUNY students were born outside the U.S. (CUNY 2018). Noemi, a community college student, noted, "I think there is a stigma also that some people don't know how to apply because I remember when I used to get food stamps, I would tell this girl in my class to apply because she didn't have money to eat. I would end up sharing my sandwich or whatever I brought with her. And she told me that she didn't know how to apply and that her mom was undocumented. But I told her it was okay because the case is for her because my parents are also undocumented. So, I don't know if she ended up doing that, but some people I guess they just don't know how to apply. Also, some of my friends are undocumented so I don't even think they can apply."

The Trump Administration's implementation of the public charge rule in 2020 increased confusion and fear among immigrant households in need of food assistance. Historically, the public charge rule prevented immigrants who were likely to become wards of the state from entering the country or becoming a U.S. citizen. Prior to the Trump administration, public charge language was defined narrowly. It required immigrants to prove that they are not likely to become dependent on the government for cash assistance or long-term care - what this typically means is long term reliance on disability benefits. However, the Trump administration's public charge rule expanded the definition of a public charge to include people who have received any public benefits including health insurance and SNAP. The rule change was briefly implemented before being struck down by the courts in March 2021. However, the proposal and the controversy surrounding it has sown considerable fear and confusion among immigrant households, leading to fewer immigrants accessing SNAP, WIC, and even food pantries (Evich 2018). David, a community college student, reported being hesitant to apply because it might impact his ability to sponsor his parent in the future. "I don't know if I would apply. Maybe now I would again, but so my mom is undocumented and so now I'm 21, I want to apply for I guess a sponsorship for her to get her green card and I guess the whole point of it is to show that you're not gonna receive government assistance or anything. So, I guess when I get everything ready and I can finally apply for her then I wouldn't."

\section{Discussion}

The fallout from the COVID 19 pandemic alongside increased attention to campus food insecurity has produced a flurry of SNAP policy modifications for students in the past few years. States like Massachusetts, Pennsylvania, and New York have expanded access to SNAP for community college students (Burnside \& Gilkesson 2021). They have designated enrollment in any community college program as an employment training program or have designated more community college programs as work training programs so that students in these programs meet one of the federal exemptions for SNAP. These policy changes make it easier for some community college students to access SNAP, but they are geographically limited and do not address the enrollment challenges faced by students in 4 year and graduate degree programs.

The federal COVID relief bill passed in December 2020 expanded SNAP eligibility for college students for the duration of the pandemic. The bill added new exemptions for students whose estimated family contribution is $\$ 0$ on their Free Application for Federal Student Aid (FAFSA) and for students who are eligible for work study, even if they do not currently have a work study position. Researchers project that these temporary changes could impact up to 3 million college students if colleges and local SNAP administrators are able to overcome bureaucratic hurdles, including getting students the documentation they need to prove their eligibility and communicating the rules to newly eligible students (Granville 2021).

However, these new state and federal approaches to expanding eligibility still conform to the logic of the original SNAP restrictions put in place in the 1980's-that students are generally undeserving unless they can prove otherwise. The new policies expand the number of students who can prove themselves deserving, but students will still have to document that they meet an exemption and will be subject to a higher administrative burden than other SNAP applicants. For CUNY students, complicated restrictions and administrative hurdles for SNAP keep eligible students from accessing the support they need through both direct and indirect exclusion. Subjecting students to greater scrutiny than other SNAP applicants is a remnant of the Reagan era belief that affluent, undeserving students might take advantage of the program and is part and parcel of the larger project of privatizing the costs of higher education for individuals and families (Cooper 2017).

By asking where the belief about undeserving college students came from in the first place, we can see how it continues to shape policies in ways that maintain barriers to SNAP for food insecure CUNY students. As with other public programs, increased administrative burdens for college 
students contribute to low enrollment. These restrictions were instituted in an era when low-income college students had more options for financial support in the form of cash assistance programs. Today, far more low-income students enroll in higher education and face increased pressures to work or to take on high levels of debt while they are in college (Goldrick-Rab 2016). Getting rid of SNAP restrictions completely for college students at the federal level would remove the administrative burdens to enrollment - including the ones that are still embedded in the temporary expansion of exemptions included in the pandemic relief bill.

SNAP restrictions for students also increase the administrative burden for campuses attempting to assist students in the application process. Some employees at CUNY who assist with benefits enrollment go to great lengths to help students qualify for food assistance. Eliminating special restrictions for college students, rather than adding to an already complex list of student exemptions, would make it easier for staff on college campuses to assist students with SNAP applications and to do the kind of broad-based outreach that has successfully increased rates of SNAP enrollment in other segments of the population (Finkelstein \& Notowidigdo 2019; Vigil 2019). Further, policy makers should designate college enrollment as work or employment so that no college students who meet the income criteria would be subject to any other SNAP work requirements. Removing these restrictions would be a significant step to address food insecurity among college students. It would also be a way to acknowledge and undo the harm that the politics of deservingness has done to low-income college students who have been denied SNAP benefits for decades.

The failure to historicize campus food insecurity has produced a skewed picture of both the causes and the cure. The basic premise of much of the campus food insecurity research is that a college degree 'pays dividends' in the form of higher lifetime earnings (Broton \& Cady 2020; Freudenberg et al. 2019). The argument goes that food insecurity makes college completion less likely and, therefore, efforts focused getting more food to students is a way to support college persistence and lifetime financial stability. Expanding access to SNAP among the truly needy becomes the policy goal. But this narrow view misses the bigger picture of how higher education replicates and contributes to race and class inequalities.

SNAP restrictions for students were not a good faith attempt to rationally allocate limited funds to the most deserving. Instead, policy makers popularized a belief about affluent college students taking advantage of public benefits in an attempt to re-privatize the costs of pursuing a higher education and to curtail the reach of public assistance programs. These efforts were part of a larger backlash to some of the key gains of the Civil Rights movement. The result of these policies has been that as educational access has increased across the population, so too has economic inequality. The current system reflects and reinforces deeply entrenched disparities (Cottom 2017; Taylor 2020). As several scholars have noted, higher education does not erase the racial disparities in a system where Black students are more likely to be enrolled in expensive, for-profit institutions, carry higher debt loads, and continue to face discrimination in the job market even with a degree (Brown 2021; Cottom 2017; Hamilton et al. 2015).

As Tressie McMillan Cottom points out, education has become more important and more risky for low income individuals because we have a broken labor market in the U.S. that does not provide adequate employment and a broken welfare system that does not provide adequate financial support for people who are left out of the labor market (Cottom 2017). More and more people are pursuing higher education in an attempt to secure credentials that may or may not lead to well-paid work in a context where failing to do so, particularly for racialized people who have been prevented from accruing generational wealth, almost certainly consigns them to poverty. The shift from public funding for free or nearly free public higher education in the Civil Rights era to the privatization of the costs of college, which included cutting public assistance like SNAP for students, is a part of these larger transformations in higher education and the labor market.

Rather than seeing college students as deserving strivers, we must understand the context in which so many more students are pursuing a college education and the ways the costs of college have shifted from the state to the individual. SNAP restrictions for students were part and parcel of this larger political project. This history and the ongoing impact on today's college students asks us to move beyond the politics of deservingness and to question the received common sense about why college students were pushed off of SNAP in the first place.

Supplementary Information The online version contains supplementary material available at https://doi.org/10.1007/s10460-021-10273-3.

Acknowledgements This study was funded by a Tufts/UConn RIDGE grant. Most importantly, I would like to thank the students at CUNY who shared their insights and experiences with us. I also want to thank Nicholas Freudenberg, Morgan Ames, Rositsa Ilieva, Huihui Li, and CUNY's Office of Institutional Research for their contributions to the research process. Jan Poppendieck and Norbert Wilson offered incredibly helpful comments on early drafts of this work and Craig Willingham and Patricia Lamberson's administrative support on this project was invaluable. Special thanks goes to the anonymous reviewers whose generous and thoughtful comments greatly improved this paper. Finally, thanks to karen g. williams, Andrea Morrell, Akissi Britton and Javiela Evangelista for keeping me going.

Funding This study was funded by a Tufts/UConn RIDGE Grant.

Data availability Data is available upon request. 
Code availability NA.

\section{Declarations}

Conflict of interest The author declare that he has no conflict of interest.

Ethical approval This research was approved by Guttman Community College's Institutional Review Board for research with human subjects.

Informed consent Informed consent was obtained from all individual participants included in the study.

\section{References}

CUNY. 2018. A Profile of Undergraduates at CUNY Senior and Community Colleges. https://www.cuny.edu/wp-content/uploads/ sites/4/page-assets/about/administration/offices/oira/institutio nal/data/current-student-data-book-by-subject/ug_student_profi le_f17.pdf. Accessed 6 May 2021.

Blagg, K., Gunderson, C., Schanzenbach, D., \& Ziliak, J. 2017. Assessing Food Insecurity on Campus. Urban Institute.

Broton, K., and C. Cady. 2020. Food insecurity on campus: Action and intervention. Baltimore, MD: Johns Hopkins University Press.

Brown, D. 2021. College isn't the solution for the racial wealth gap. It's part of the problem. Washington Post. April 9.

Bruening, M., K. Argo, D. Payne-Sturges, and M. Laska. 2017. The struggle is real: a systematic review of food insecuritiy on postsecondary campuses. Journal of the Academy of Nutrition and Dietetics 117 (11): 1767-1791.

Burnside, A., \& Gilkesson, P. (2021). Connecting Community College Students to SNAP. CLASP. https://www.clasp.org/publicatio $\mathrm{ns} /$ report/brief/connecting-community-college-students-snap. Accessed 10 May 2021.

Charlton, L. 1971. Federal Food Stamp Programs for Poor Gains Wide Popularity With Students. The New York Times. January 14.

Clarke, M., Delgado, K., Dickinson, M., Galvez, A., Garot, R., Mercado, I., Freudenberg, N. 2018. Ending Food Insecurity at CUNY: A Guide for Faculty and Staff. CUNY Urban Food Policy Institute. http://www.cunyurbanfoodpolicy.org/publications/. Accessed 1 May 2021.

Cooper, M. 2017. Family values: Between neoliberalism and the new social conservatism. Cambridge, MA: Zone Books.

Cottom, T. M. (2017) Lower ed the troubling rise of for-profit college. The New Press, NY

Cunnyngham, K. 2018. Trends in Supplemental Nutrition Assistance Program Participation Rates: Fiscal Year 2010 to Fiscal Year 2016. USDA.

Davis, D.A., and C. Craven. 2016. Feminist ethnography: thinking through methodologies, challenges, and possibilities. Lanham MD: Rowman and Littlefield.

Davis, D. A. 2013. Crossing Borders: Feminist Activist Ethnography, Intimacy, and the Neoliberal Mix. In C. Craven \& D. A. Davis (Eds.), Feminist activist ethnography: Lexington Books.

Dickinson, M. 2016. Working for food stamps: Economic citizenship and the post-Fordist welfare state. American Ethnologist 43 (2): 270-281.

Dickinson, M. 2020. Feeding the crisis: Care and abandonment in America's food safety net. Berkeley, CA: University of California Press.

DSS. 2020. New York Department of Social Services.
Duke-Benfield, A. E., \& Chu, S. 2020. Addressing Student Hunger through Policy Change. In Food insecurity on campus: action and intervention: Johns Hopkins Press.

Evich, H. B. 2018. Immigratns, fearing Trump crackdown, drop out of nutrition programs. Politico. September 3.

Finkelstein, A., and M. Notowidigdo. 2019. Take-up and targeting: Experiential evidence from SNAP. The Quarterly Journal of Economics 134 (3): 1505-1556.

Freudenberg, N., S. Goldrick-Rab, and J. Poppendieck. 2019. College students and SNAP: The new face of food insecurity in the United States. American Journal of Public Health 109 (12): $1652-1658$.

GAO. 2019. Food Insecurity: Better Information Could Help Eligible College Students Access Federal Food Assistance Benefits. Government Accountability Office.

Gilmore, R.W. 2007. Golden gulag: Prisons, surplus, crisis and opposition in globalizing California. Berkely, CA: University of California Press.

Gittell, M. 1996. How Welfare Recipients Succeed at CUNY. CUNY Matters. Summer 1996.

Glaser, B., and A. Strauss. 1967. The discovery of grounded theory: Strategies for qualitative research. Chicago: Aldine Publishing Company.

Goldrick-Rab, S. 2016. Paying the price: College costs, financial aid, and the betrayal of the American dream. Chicago: University of Chicago Press.

Goldrick-Rab, S., Richardson, J., \& Hernandez, A. 2017. Hungry and Homeless in College. Hope Lab. https://hope4college.com/ wp-content/uploads/2018/09/Hungry-and-Homeless-in-CollegeReport.pdf. Accessed 20 May 2021.

Goldrick-Rab, S., Coca, V., Baker-Smith, C., \& Looker, E. 2019. City University of New York \#RealCollege Survey. Hope Lab. https:// hope4college.com/city-university-of-new-york-realcollege-survey/. Accessed 22 May 2021.

Granville, P. 2021. Congress Made 3 Million College Students Newly Eligible for SNAP Food Aid. The Century Foundation. https:// tcf.org/content/commentary/congress-made-3-million-colle ge-students-newly-eligible-snap-food-aid-heres-must-comenext $/$ ?agreed $=1$ \&session $=1$ \&agreed $=1$ \&agreed $=1$ \&agreed $=1$. Accessed 15 July 2021.

Hagar, E., A. Quigg, M. Black, S. Coleman, T. Heeren, R. RoseJacobs, and D. Frank. 2010. Development and validity of a 2 -item screen to identify families at risk for food insecurity. Pediatrics 121 (1): 65-72.

Hamilton, D., Darity, W., Price, A., Sridharan, V., \& Tippett, R. 2015. Umbrellas Don't Make it Rain: Why Studying and Working Hard isn't Enough for Black Americans. Duke Center for Social Equity.

Hancock, A.-M. 2004. The politics of disgust: The public identity of the welfare queen. New York: NYU Press.

Haney-Lopez, I. 2014. Dog whistle politics: How coded racial appeals reinvented racism and wrecked the middle class. New York: Oxford University Press.

Harrison, F. 2007. Feminist Methodology as a Tool for Ethnographic Inquiry on Globalization. In The gender of globalization: Women navigating cultural and economic marginalities, ed. N. Gunewardena and A. Kingsolver, 23-34. Santa Fe: School for Advanced Research Press.

Healthy CUNY. 2020. The State of Food Security at CUNY in 2020: An Assessment and Recommendations. CUNY Urban Food Policy Institute.

Herd, P., and D. Moynihan. 2018. Administrative burden: Policymaking by other means. New York: Russell Sage Foundation.

Hinton, E. 2016. From the war on poverty to the war on crime: The making of mass incarceration in America. Cabridge, MA: Harvard University Press. 
Jaffe, S. 2021. Work won't love you back: How devotion to our jobs keeps us exploited, exhausted, and alone. New York: Bold Type Books.

Katznelson, I. 2005. When affirmative action was white: The untold history of racial inequality in twentieth century America. New York: W.W. Norton.

King, S. 1975. Many University Students are Turning U.S. Food Stamps Into a Form of Scholarship. The New York Times. January 2.

Laterman, K. 2019. Tuition or Dinner? Nearly Half of College Students Surveyed in a New Report are Going Hungry. The New York Times. May 2.

Nadasen, P. 2004. Welfare warriors: The welfare rights movement in the United States. New York: Routledge.

Nikolaus, C., B. Ellison, and S. Nickols-Richardson. 2019. Are estimates of food insecurity among college students accurate? Comparision of Assessment Protocols. Plos One 14 (4): e 0215161.

Patton-Lopez, M., D. Lopez-Cevallos, D. Cancel-Tirado, and L. Vazquez. 2014. Prevalance and Correlates of food insecurity among students attending a midsize rural university in Oregon. Journal of Nutrition Education and Behavior 46 (3): 209-214.

Payne-Sturges, D., A. Tjaden, K. Caldeira, K. Vincent, and A. Arria. 2018. Student hunger on campus: Food insecurity among college students and implications for academic institutions. American Journal of Health Promotion 32 (3): 349-354.

Pearson, A.F. 2007. The new welfare trap: Case managers, college education, and TANF policy. Gender and Society 21 (5): 723-748.

Peterson, N.D., and A. Freidus. 2020. More than money: Barriers to food security on a college campus. Culture, Agriculture, Food and Environment. 42 (2): 125-137.

Piven, F.F., and R. Cloward. 1979. Poor people's movements: Why they succeed, how they fail. New York: Vintage books.

Poppendieck, J. 1998. Sweet charity: Emergency food and the end of entitlement. New York: Viking Press.

Quadagno, J. 1996. The color of welfare how racism undermined the war on poverty. Oxford, New York

Roberts, S. 1981. Food Stamps Program: How it Grew and How Reagan Wants to Cut it Back. The New York Times. April 4.
Safawi, A., \& Floyd, I. 2020. TANF Benefits Still Too Low to Help Families, Especially Black Families, Avoid Increased Hardship. Center on Budget and Policy Priorities.

Saldaña, J. 2014. Coding and Analysis Strategies. In The Oxford handbook of qualitative research, ed. P. Leavy. Oxford: Oxford University Press.

Schott, L. 2020. State General Assistance Programs Very Limited in Halt the States and Nonexistent in Others, Despite Need. Center on Budget and Policy Priorities.

Shaefer, H. L., \& Edin, K. 2012. Extreme Poverty in the United States, 1996 - 2011. National Poverty Center.

Shaw, K., S.G. Rab, C. Mazzeo, and J.A. Jacobs. 2006. Putting poor people to work: how the work-first idea eroded college access for the poor. New York: Russell Sage Foundation.

Soss, J., R. Fording, and S. Schram. 2011. Disciplining the poor: Neoliberal paternalism and the persistent power of race. Chicago and London: University of Chicago Press.

Taylor, A. 2020. The End of the Univerisitiy. The New Republic. September 8 .

USDA. 2020. Definitions of Food Security. https://www.ers.usda.gov/ topics/food-nutrition-assistance/food-security-in-the-us/defin itions-of-food-security.aspx. Accessed June 2, 2021.

Vigil, A. 2019. Trends in Supplemental Nutrition Assistance Program Participation Rates: Fiscal Year 2010 to Fiscal Year 2017. USDA.

Publisher's Note Springer Nature remains neutral with regard to jurisdictional claims in published maps and institutional affiliations.

Maggie Dickinson is Associate Professor of Interdisciplinary Studies at CUNY's Guttman Community College and the author of Feeding the crisis: care and abandonment in America's food safety net (University of California Press 2020). 